\title{
Pengaruh Pembangunan Infrastruktur Terhadap Peningkatan Ekonomi Masyarakat Di Kabupaten Sinjai
}

\author{
The Effect of Infrastructure Development on Community Economic \\ Improvement in Sinjai District
}

\author{
Bambang Tri Utomo \\ Magister Perencanaan Wilayah dan Kota Program Pascasarjana Universitas Bosowa \\ E-mail: triutomo6117@gmail.com
}

Diterima: 20 Februari 2019/Disetujui 07 Juni 2019

\begin{abstract}
Abstrak. Kondisi ekonomi masyarakat khususnya di perdesaan masih sangat rendah, hal ini akibat karena pembangunan jalan sebagai salah satu sistim jaringan yang berfungsi untuk menghubungkan antara satu wilayah dengan wilayah lainnya, atau antara desa dengan desa lainnya, belum dilaksanakan secara prioritas sesuai dengan prinsip bottom-up, yaitu aspirasi kebutuhan prioritas masyarakat yang diusulkan ke pihak pemerintah daerah perlu diwujudkan. Melalui Program Nasional Pemberdayaan Masyarakat-Pembangunan Infrastruktur Sosial Ekonomi Wilayah (PNPM-PISEW), yang telah digulirkan oleh pemerintah pusat yang saat ini mulai dirasakan oleh masyarakat. Rumusan masalah Bagaimana Pengaruh Pembangunan Infrastruktur Jalan pada aspek Keterbukaan isolasi, aksesibilitas dan partisipasi masyarakat desa terhadap pengembangan ekonomi masyarakat? Tujuan penelitian adalah menganalisis Pengaruh Pembangunan Infrastruktur Jalan pada aspek Keterbukaan isolasi, aksesibilitas dan partisipasi masyarakat desa terhadap pengembangan ekonomi masyarakat Kecamatan Sinjai Selatan dan Kecamatan Tellulimpoe Kabupaten Sinjai. Jenis penelitian merupakan deskriptif analisis kualitatif melalui jawaban responden yang diambil diwilayah penelitian didua Kecamatan, selanjutnya tabulasi data diproses dengan menggunakan Skala Likert dan metode Prosentase. Hasil pembahasan yaitu bahwa ketiga variabel infrastruktur, aksesibilitas dan partisipasi masyarakat, terhadap pengembangan ekonomi masyarakat desa khususnya di dua kecamatan. Hasil yang diperoleh melalui metode Skala Likert, maka ketiga variable terukur dalam skala Baik, sebelum program jalan terbangun pendapatan petani antara 1,5-2 juta rupiah perbulan, dan setelah terbangunnya jalan nilai ekonomi dari tahun ke tahun meningkat kurang lebih 3 juta rupiah perbulan pada tahun pertama operasional jalan
\end{abstract}

Kata Kunci: Pengembangan, Ekonomi, Infrastruktur, Aksesibilitas, Partisipasi

\begin{abstract}
The economic condition of the community, especially in rural areas, is still very low, this is due to road construction as a network system that functions to connect one region to another, or between villages and other villages, has not been implemented in priority according to the bottom-up principle, that is, the aspirations of the community's priority needs proposed to the local government need to be realized. Through the National Program for Community Empowerment Regional Socio-Economic Infrastructure Development (PNPM-PISEW), which has been rolled out by the central government which is now beginning to be felt by the community. Formulation of the problem How are the Effects of Road Infrastructure Development on aspects of openness of isolation, accessibility and participation of rural communities to the economic development of the community? The aim of the study was to analyze the effect of road infrastructure development on aspects of openness of isolation, accessibility and participation of rural communities in the economic development of the community of South Sinjai Subdistrict and Tellulimpoe District, Sinjai District. This type of research is descriptive qualitative analysis through respondents' answers taken in the research area in two subdistricts, then the tabulation of data is processed using a Likert Scale and Percentage method. The results of the discussion are that the three infrastructure variables, accessibility and community participation, on the economic development of rural communities, especially in the two sub-districts. The results obtained through the Likert Scale method, then the three measured variables are on a Good scale, before the road program is built the farmers' income is between 1.5-2 million rupiah per month, and after the construction of the road the economic value from year to year increases by approximately 3 million rupiah per month first year of road operations.
\end{abstract}

Keywords: Development, Economy, Infrastructure, Accessibility, Participati

\section{Pendahuluan}

Kondisi ekonomi masyarakat khususnya di perdesaan masih sangat rendah, hal ini akibat karena pembangunan jalan sebagai salah satu sistim jaringan yang dapat berfungsi untuk menghubungkan antara satu wilayah dengan wilayah lainnya, atau antara desa dengan desa lainnya, belum dilaksanakan secara prioritas sesuai dengan prinsip bottom-up, yaitu aspirasi kebutuhan prioritas masyarakat yang diusulkan ke pihak pemerintah daerah perlu diwujudkan. 
Melalui Program Nasional Pemberdayaan Masyarakat- Pembangunan Infrastruktur Sosial Ekonomi Wilayah (PNPM-PISEW), yang telah digulirkan oleh pemerintah pusat yang saat ini mulai dirasakan oleh masyarakat.

Kehadiran PNPM-PISEW yang telah ada sejak 2014 lalu yang berorientasi pada pembangunan infrastruktur khususnya prasarana jalan telah dimanfaatkan masyarakat, sehingga untuk mengetahui sejauhmana perkembangan ekonomi masyarakat di kedua kecamatan mengalami perubahan sesuai dengan salah satu tujuan program yaitu peningkatan ekonomi masyarakat. Hal inilah yang menjadi dasar sehingga mengangkat judul Pengaruh Pembangunan Infrastruktur Jalan Terhadap Perkembangan Ekonomi Masyarakat melalui PNPM-PISEW di Kabupaten Sinjai.

Polemik mengenai kesenjangan secara umum diartikan sebagai kondisi yang tidak seimbang antara satu komunitas dengan komunitas lainnya. Kondisi keadilan dalam pembangunan antar suatu wilayah, selalu menjadi perbincangan hangat, terutama terkait dengan masalah "kesenjangan wilayah" (regional imbalances). Sampai saat ini isu kesenjangan wilayah terpusat kepada kesenjangan antara desa dan kota, antara wilayah di suatu Negara yaitu; Wilayah Timur Indonesia dan Wilayah Barat Indonesia, atau antara Jawa dan luar Jawa.

Banyak pakar yang percaya bahwa kesenjangan wilayah merupakan harga wajar yang harus dibayar dalam proses pembangunan. Sederhana saja alasannya, yakni ada keterkaitan antara wilayah satu dengan wilayah yang lain sebagai sebuah sistem. Dengan kata lain ada proses interaksi dan interdependensi antar subsistem.

Indikator yang digunakan untuk memperlihatkan bahwa sebuah wilayah dianggap lebih maju dibandingkan dengan wilayah yang lainnya cukup banyak. Hill (1993) misalnya menyebut indikator yang bersifat statis seperti Indeks Pembangunan Manusia (human development index), Indeks Kualitas Kehidupan secara Fisik (physical quality of life index), maupun laju PDRB (product domestic regional bruto). Data seperti ini meskipun tidak secara absolut dapat dipercaya begitu saja, namun dapat digunakan sebagai gambaran awal betapa sebuah wilayah lebih maju dibanding dengan wilayah lain.

Fakta juga menunjukkan bahwa pembangunan sebuah wilayah dipengaruhi oleh sebuah faktor penting, yakni investasi pembangunan daerah, sedangkan kesenjangan wilayah terjadi jika alokasi investasi antar daerah juga timpang (Aziz,1985).

Menurut Syamsi Yuswar Zainul Basri \& Mulyadi Subri (2006:15) pembangunan adalah proses perubahan sistem yang di rencanakan kearah perbaikan yang orientasinya pada modernis pembangunan dan kemajuan sosial ekonomis. Konsep pembangunan itu merupakan kunci pembuka bagi pengertian baru tentang hakekat fungsi administrasi pada setiap negara dan sifat dinamis. Pembangunan akan dapat berjalan lancar, apabila disertai dengan admnistrasi yang baik.

Pembangunan merupakan suatu proses pembaharuan yang berkelanjutan dan terus menerus dari suatu keadaan tertentu kepada suatu keadaan yang dianggap lebih baik. Sedangkan menurut Sondang P.Siagian, (2008) pembangunan merupakan suatu rangkaian usaha untuk mewujudkan pertumbuhan dan perubahan secara terencana serta sadar, yang di tempuh oleh suatu negara menuju modernitas dalam rangka pembinaan bangsa.
Sedangkan menurut Saul M. Katz dalam Yuwono (2001:47) pembangunan sebagai perubahan sosial yang berasal dari suatu keadaan tertentu keadaan yang dipandang lebih bernilai. Maka untuk mencapai pembangunan nasional yang berkeadilan itu, berbagai usaha telah dilakukan pemerintah. Pembangunan yang telah dicanangkan selama ini dapat berjalan sesuai dengan bersama apabila mendapat tanggapan yang positif dari masyarakat, seperti yang dikemukakan oleh Gran dalam Yuwono (2001:54).

Pembangunan terdiri dari pembangunan fisik dan non fisik. Pembangunan fisik adalah pembanguan yang dapat di rasakan langsung oleh Masyarakat atau pembangunan yang tampak oleh mata (Kuncoro 2010:20) pembangunan fisik misalnya berupa infrastruktur, bangunan, fasilitas umum. Sedangkan pembangunan non fisik adalah jenis pembangunan yang tercipta oleh dorongan masyarakat setempat dan memiliki jangka waktu yang lama (Wresniwiro, 2012) contoh dari pembangunan non fisik adalah berupa peningkatan perekonomian rakyat desa, peningkatan kesehatan masyarakat.

Akhirnya disadari bahwa pengertian pembangunan itu sangat luas bukan hanya sekedar bagaimana menaikkan pendapatan nasional saja. Pembangunan ekonomi itu tidak bisa diartikan sebagai kegiatan-kegiatan yang dilakukan negara untuk mengembangkan kegiatan ekonomi dan taraf hidup masyarakatnya. Teori pertumbuhan wilayah dimulai dari model dinamika wilayah yang sederhana sampai dengan model yang komprehensif, mulai dari teori resource endowment teori export base, teori pertumbuhan wilayah neoklasik, model ketidakseimbangan pertumbuhan wilayah dan sebuah teori baru mengenai pertumbuhan wilayah. Teori resource endowment mengatakan bahwa pengembangan ekonomi bergantung sumberdaya alam yang dimiliki dan permintaan terhadap komoditas yang dihasilkan dari sumberdaya itu (Perloff \& Wingo, 1961).

Dalam praktik pembangunan di Indonesia, kebijakan pembangunan cenderung lebih memihak pada pembangunan perkotaan dibandingkan pembangunan pedesaan. Akibatnya, terjadi kesenjangan pertumbuhan dan perkembangan ekonomi antara perkotaan dan pedesaan.

Infrastruktur adalah sebuah sistem fasilitas publik, yang bersifat fundamental di tujukan kepada masyarakt/khalayak ramai untuk melayani dan memudahkan masyarakat (Hudson, et al:1997). secara umum, infrastruktur adalah istilah yang berhubungan maknanya dengan struktur di bawah struktural (structure beneath a structureal). Definisi ini mengimplikasikan adanya perbedaan layer (lapisan) dari stuktur yang ada, ibaratnya menyediakan support atau layanan (service). Dalam dunia fisik, terminologi infrastruktur kadang merujuk kepada keperluan-keperluan publik, seperti air, listrik, gas, pembuangan air, dan layanan telepon. di infrastruktur memiliki beberapa karakteristik tertentu, termasuk:1) Digunakan bersama-sama (shared) oleh pengguna yang lebih luas, ketimbang stuktur-struktur yang didukungnya, 2) Lebih statis dan permanen ketimbang struktur-struktur yang didukungnya, 3).Lebih dipandang sebagai sebuah service (considered a service), termasuk orang-orang dan proses yang dilibatkan dalam support, lebih dari sekedar sebuah struktur atau perlengkapan (device) fisik, 4)Terkadang terhubung secara fisik ke struktur yang didukungnya, 5) Terpisah (distinct) dari 
strktur-struktur yang didukungnya dalam hal kepemilikannya dan orang-orang.

Sedangkan menurut para ahli yang lain Infrastruktur mengacu pada sistem fisik yang menyediakan transportasi, air, bangunan, dan fasilitas publik lain yang diperlukan untuk memenuhi kebutuhan dasar manusia secara ekonomi dan sosial (Socrates: 2001). Terhambatnya dinamika masyarakat desa antara lain disebabkan oleh keterisolasian desa terhadap aksesibilitas yang ada. Desa yang terisolasi atau desa yang tidak memiliki aksesibilitas sebagai jaringan transportasi pada berbagai sumber-sumber daya alam potensi yang ada didesa akan menjai sulit untuk mengembangkan desa dan masyarakatnya sehingga sulit meningkatkan ekonominya secara berkelanjutan.

Dalam hal ini kawasan desa yang terpencil dan jauh serta tidak diakses dengan jaringan jalan desa yang memadai, sangat sulit kemungkinannya untuk meningkatkan kemajuan ekonomi masyarakatnya. Dalam kondisi ini para sosiologi dalam menganalisis perubahanperubahan dalam masyarakat mengemukakan bahwa penyebab dari perubahan soial antara lain adalah lingkungan alam, perubahan penduduk, isolasi desa interaksi soial dan struktur budaya (Daldjoeni 1989:3).

Faktor-faktor yang mempengaruhi tingkat dan arah perkembangan desa mencakup faktor lokasi desa terhadap sentra fasilitas dan jalan penghubung (lancar atau tidak lancar). Lokasi mengandung arti jarak suatu tempat dengan tempat alain atau jarak satu desa dengan desa lainnya sebagai fungsi aksesibilitas dipengaruhi oleh kondisi prasarana jalan yang akan memberi pengaruh terhadap kelancaran dan komunikasi.

Bahwa jarak desa terhadap ibukota provinsi, kabupaten dan kota kecamatan sangat dipengaruhi oleh kondisi jalan, kelas jalan, jarak tempuh sebagai faktorfaktor penyebab adanya desa terisolir (Sayogyo,1986:156159). Keterisolasian ini berhubungan dengan kesediaan sarana dan prasarana yang menghubungkan desa dengan sentra-sentra pemasaran (Leibo 1994). Dalam praktik pembangunan di Indonesia, kebijakan pembangunan cenderung lebih memihak pada pembangunan perkotaan dibandingkan pembangunan pedesaan. Akibatnya, terjadi kesenjangan pertumbuhan dan perkembangan ekonomi antara perkotaan dan pedesaan. Dengan ketersediaan infrastruktur yang lebih memadai, aktivitas perekonomian di kawasan perkotaan semakin berkembang, sedangkan kawasan pedesaan yang minim akan infrastruktur menjadi semakin tertinggal dari ekonomi perkotaan.

Minimnya infrastruktur di pedesaan tersebut salah satunya yaitu dalam bidang transportasi. Minimnya sarana dan prasarana transportasi menyebabkan sulitnya akses bagi masyarakat pedesaan sehingga perekonomian pedesaan tumbuh sangat tertinggal dibanding perkotaan. Apalagi secara spasial penduduk pedesaan menyebar dan terpencar-pencar dimana jarak antar satu desa dengan desa lainnya cukup jauh. Dengan tingkat aksesibilitas rendah tentunya akan sulit terjadi interaksi antar desa.

Berdasarkan hal tersebut maka untuk mendorong perekonomian pedesaan salah satunya melalui aksesibilitas. Aksesibilitas sendiri dapat didefinisikan sebagai tingkat kemudahan untuk mencapai atau mendapatkan barang dan jasa yang diperlukan. Aksesibilitas yang tinggi dapat tercipta dengan ketersediaan prasarana (jaringan jalan) yang baik dan didukung dengan ketersediaan sarana atau fasilitas untuk melakukan pergerakan. Aksesibilitas yang tinggi ini juga dapat diukur berdasarkan jarak lokasi ke pusat-pusat pelayanan publik yang secara spasial identik dengan pusat kota.

Dalam kawasan pedesaan, aksesibilitas memiliki peranan yang penting. Keberadaan aksesibilitas ini dapat merangsang tumbuhnya pasar dan pusat pertumbuhan ekonomi dalam suatu wilayah desa. Dengan kemudahan aksesibilitas, interaksi suatu desa dengan desa lainnya akan semakin mudah. Dengan kemudahan aksesibilitas, produktivitas pertanian juga akan meningkat. Namun, di sisi lain dengan berkembangnya aktivitas di daerah pedesaan dengan aksesibilitas tinggi, terutama di pusat pertumbuhan desa menyebabkan karakteristik sosial ekonominya menjadi berbeda, lebih cenderung berkembang dan bersifat seperti kawasan perkotaan.

Aksesibilitas merupakan suatu tingkat kemudahan bagi seseorang untuk mencapai suatu lokasi tertentu. Aksesibilitas ini sangat terkait dengan jarak lokasi suatu daerah terhadap daerah lainnya khususnya jarak lokasi ke pusat-pusat pelayanan publik (public service) yang secara spasial identik dengan ibu kota propinsi dan ibukota kabupaten/kota. Selain terkait dengan jarak lokasi, aksesibilitas juga terkait dengan waktu dan biaya.

Konsep partisipatif mengandung makna luas dan arti yang amat dalam, dimana pada proses pembangunan partisipasi itu berfungsi sebagai masukan dan keluaran. Sebagai masukan partisipasi dapat berfungsi pada fase penerimaan informasi, fase pemberian tanggapan terhadap informasi, fase perencanaan pembangunan, fase pelaksanaan pembagunan, penerimaan kembali hasil pembangunan dan fase penilaian pembangunan, sehingga partisipasi befungsi menumbuhkan masyarakat untuk berkembang secara mandiri.

Partisipasi adalah keikutsertaan, perhatian dan sumbangan yang diberikan oleh kelompok yang berpatisipasi, dalam hal ini adalah masyarakat (Pasaribu, 1992). Untuk menumbuhkan dan menggerakan semangat partisispasi, diperlukan prasyarat yang dapat membangkitkan tenaga sosial dalam masyarakat. Partisipasi sebenarnya sangat beranekaragam, bukan sekedar perkumpulan masyarakat disatu tempat tertentu untuk mendengarkan penjelasan mengenai- yang dilarang dari atas.

Partisipasi adalah sebuah bentuk keterlibatan mental/pikiran dan emosi atau perasan seseorang dalam situasi kelompok yang mendorongnya untuk memberikan sumbangan kepada kelompok dalam usaha mencapai tujuan serta turut tanggung jawab terhadap usaha yang bersangkutan (Keith Davis dalam Sastropoetro, 1998).

Ada tiga unsur penting yang dimaksud dalam definisi Keith Davis tentang partisipasi, yang memerlukan perhatian khusus yaitu: (1) bahwa partisipasi atau keikutsertaan (keterlibatan/peran serta) sesungguhnya merupakan suatu keterikatan mental dan perasaan, lebih daripada kata-kata atau hanya keterlibatan secara jasmaniah; (2) ketersediaan memberi suatu sumbangan kepada usaha mencapai tujuan kelompok, ini berarti bahwa terdapat rasa senang, kesukarelaan untuk membantu 
kelompok. Seseorang menjadi anggota dalam kelompok dengan segala nilainya; (3) unsur tanggung jawab, unsur ini merupakan segi yang menonjol dari rasa menjadi anggota.

Tujuan penelitian ini adalah untuk mengetahui pengaruh pembangunan infrastruktur jalan pada aspek keterbukaan isolasi desa, Pelayanan aksesibilitas dan partisipasi masyarakat terhadap pengembangan ekonomi masyarakat.

\section{Metode Penelitian}

Ditinjau dari jenis datanya pendekatan penelitian yang digunakan dalam penelitian ini adalah pendekatan kualitatif. Yang dimaksud dengan penelitian kualitatif yaitu penelitian yang bermaksud untuk memahami fenomena tentang apa yang dialami oleh subjek penelitian secara holistik, dan dengan cara deskripsi dalam bentuk kata-kata dan bahasa, pada suatu konteks khusus yang alamiah dan dengan memanfaatkan berbagai metode ilmiah (Moleong, 2007). Adapun pendekatan penelitian ini adalah jenis deskriptif. Penelitian deskriptif yaitu penelitian yang berusaha untuk menuturkan pemecahan masalah yang ada sekarang berdasarkan data-data. Jenis penelitian deskriptif kualitatif yang digunakan pada penelitian ini dimaksudkan untuk memperoleh informasi mengenai sejauh mana aspek Isolasi wilayah, aksesibilitas dan Interaksi Sosial terhadap peningkatan ekonomi masyarakat di kawasan pada kecamatan Sinjai Selatan dan Kecamatan Tellulimpoe Kabupaten Sinjai.

Sesuai dengan permasalahan yang diteliti, dalam penelitian ini dari segi kecil dengan menyeleksi dan samplingnya tergolong penelitian survei. Kerlinger (2006) menyatakan bahwa penelitian survey mengkaji populasi yang besar maupun mengkaji sampel yang dipilih dari populasi itu untuk menemukan insidensi, distribusi, dan interelasi relatif dari variabel-variabel sosiologis psikologis. Menurut Sugiono (2006), bahwa penelitian survei pada umumnya dilakukan untuk mengambil suatu generalisasi dari pengamatan yang tidak mendalam, namun generalisasi yang dilakukan bisa lebih akurat bila digunakan sampel yang representatif. Sedangkan dari sifatnya, rancangan penelitian ini bersifat deskriptif dan korelasional. Penelitian deskriptif adalah suatu penelitian yang berusaha memperoleh informasi berkenaan dengan fenomena yang diamati saat ini (Suharsimi, 1989).

Pada penelitian ini akan mendeskripsikan data tentang obyek atau variabel penelitian yang ada untuk wilayah penelitian di dua kecamatan di kabupaten Sinjai, yang mencakup variabel keterisolasian desa, aksesibilitas jalan dan Partisipasi Masyarakat, dalam kawasan bantuan program PISEW.

Penelitian ini dilaksanakan pada dua wilayah kecamatan, yaitu Kecamatan Sinjai Selatan dan Kecamatan Tellulimpoe di Kabupaten Sinjai. Pemilihan lokasi penelitian yaitu berdasarkan atas pelaksanaan PNPMPISEW yang dimulai dari tahun 2009-2012, hasil pelaksanaan kegiatan ini akan melakukan penilaian sejauhmana pengaruh pembangunan infrastruktur jalan sebagai skala prioritas pembangunan di dua kecamatan melalui aspek keterbukaan isolasi desa, pengembangan aksesibilitas jalan dan partisipasi masyarakat terhadap perubahan dan peningkatan nilai ekonomi masyarakat.

Populasi Menurut Sudjana (1992), populasi adalah keseluruhan obyek yang menjadi sasaran atau tujuan penelitian. Sejalan dengan Sudjana, Sugiyono (2001) menjelaskan bahwa populasi adalah keseluruhan komponen yang menjadi obyek suatu penelitian.

Berdasarkan hal tersebut maka populasi yang dimaksudkan dalam penelitian ini adalah seluruh populasi sebagai masyarakat di Kecamatan Sinjai Selatan yang berjumlah 26.617 Jiwa dan Kecamatan Tellulimpoe sebesar 65.280 jiwa (BPS Kecamatan Sinjai Selatan dan Kecamatan Tellulimpoe Tahun 2014). Dalam Sugyono (2003;102-103), jumlah anggota sampel sering dinyatakan dengan ukuran sampel. Berikut ini diberikan tabel penentuan jumlah sampel dari populasi tertentu yang dikembangkan dari Isaac dan Michael, untuk tingkat kesalahan, $1 \%, 5 \%$ dan $10 \%$. Rumus untuk menghitung ukuran sampel dari jumlahnya adalah sebagai berikut.

$$
S=\frac{\lambda^{2} \cdot N \cdot P \cdot Q}{d^{2}(N-1)+\lambda^{2} \cdot P \cdot Q}
$$

Dimana :

$\mathrm{S}=$ jumlah sampel

$\lambda^{2}$ dengan $\mathrm{dk}=$, taraf kesalahan bisa $1 \%, 5 \%, 10 \%$.

$\mathrm{P}=\mathrm{Q}=0,5$.

$\mathrm{D}=0,05$

Tabel 1. Penentuan Jumlah Sampel Dari Populasi Tertentu dengan Taraf Kesalahan 1\%, 5\%, dan 10\%

\begin{tabular}{cccc}
\hline \multirow{2}{*}{$\mathbf{N}$} & \multicolumn{3}{c}{ Sampel } \\
\cline { 2 - 4 } & $\mathbf{1 \%}$ & $\mathbf{5 \%}$ & $\mathbf{1 0 \%}$ \\
\hline 10 & 10 & 10 & 10 \\
15 & 15 & 14 & 14 \\
20 & 19 & 19 & 19 \\
30000 & 649 & 344 & 268 \\
40000 & 563 & 345 & 269 \\
$\infty$ & & &
\end{tabular}

Sumber: Sugiono, 2003.

Tabel 1, maka jumlah sampel yang akan diambil pada Kecamatan Sinjai Selatan dan Kecamatan Tellulimpoe adalah 269 sampel yang mewakili dari setiap kelurahan/desa. Perlu dijelaskan, sampel yang dijadikan informan penelitian ini berfungsi untuk menjawab pertanyaan penelitian yang berbentuk Angket Kuesioner. Selanjutnya untuk melengkapi data yang diperoleh melalui penyebaran angket kuesioner, juga dilakukan serangkaian wawancara secara mendalam kepada informan kunci (Key Informan). Penetapan informan kunci ini didasarkan atas kenyataan bahwa yang bersangkutan mengetahui, memahami dan mampu memberikan jawaban mengenai berbagai hal menyangkut penelitian ini.

Roscoe (1982:253), dalam buku "Research Methods For Business, memberikan saran-saran tentang ukuran sampel untuk penelitian seperti ini :

1. Ukuran Sampel yang layak dalam penelitian adalah antara 30-500 sampel

2. Bila sampel dibagi dalam kategori (Misal : Priawanita : PNS-karyawan swasta dan lainnya, maka jumlah anggota sampel setiap kategori minimal 30 sampel.

3. Bila dalam penelitian yang menggunakan analisis dengan multivariate (korelasi atau regresi berganda misalnya), maka jumlah anggota sampel minimal 10 kali dari jumlah variabel yang diteliti. Misal jumlah variabel yang diteliti 5 (independen+Dependen), maka jumlah sampel $=10 \times 5=50$ sampel.

4. Untuk penelitian eksperimen yang sederhana, yang menggunakan kelompok eksperimen dan kelompok 
control, maka jumlah anggota sampel masing-masing antara 20-30 sampel.

Pembahasan Data dilakukan dengan metode Prosentase dan Skala Likert.

\section{Metode Prosentase}

Hasil pernyataan responden pada masing-masing variabel melalui kuisioner dengan memberikan jawaban pilihan: Sangat Setuju Skor 5, Setuju Skor 4, Ragu-Ragu Skor 3, Tidak Setuju skor 2 dan Sangat Tidak Setuju Skor 1. Dengan jumlah responden yang ditetapkan. Hasil prosentase selanjutnya digambarkan melalui grafik untuk dianalisis

$$
\mathrm{P}=\mathrm{f} / \mathrm{N} \times 100 \%
$$

Di mana :

$\mathrm{P}=$ Persentase

$\mathrm{f} \quad=$ Frekuensi Jawaban Responden

$\mathrm{N}$ = Jumlah Responden (Sampel)

2. Metode Skala Likert

Indikator-indikator yang terukur ini dijadikan titik tolak untuk membuat item instrumen yang berupa pertanyaan atau pernyataan yang perlu dijawab oleh responden. penilaian dilakukan berdasarkan tingkat frekuensi jawaban tertinggi dari hasil kuesioner yang telah diperoleh. Nilai 5 untuk jawaban (a), nilai 4 untuk jawaban (b), nilai 3 untuk jawaban (c), nilai 2 untuk jawaban (d) dan nilai 1 untuk jawaban (e). Dimana penilaian tersebut menunjukkan tingkat pengaruh/dampak indikator penelitian terhadap pengembangan ekonomi local di lokasi penelitian.

Dengan skala Likert, maka variabel yang akan diukur dijabarkan menjadi indicator variabel. Kemudian indikator tersebut dijadikan sebagai titik tolak untuk menyusun itemitem instrument yang dapat berupa pernyataan atau pertanyaan. Jawaban setiap item instrumen yang menggunakan skala Likert mempunyai gradasi jawaban dan skor sebagai berikut :

Secara kuantitatif sebagaimana contoh dibawah ini :

a. Jawaban Sangat Setuju dengan symbol (ST) dengan skor 5

b. Jawaban Setuju dengan symbol (S) dengan skor 4

c. Jawaban Ragu-Ragu dengan symbol (RG) dengan skor 3

d. Jawaban Tidak Setuju dengan symbol (TS) dengan skor 2

e. Jawaban Sangat Tidak Setuju dengan symbol (STS) dengan skor 1

Semakin tinggi nilai penilaian tersebut menunjukkan bahwa dampak yang ditimbulkan semakin tinggi terhadap pengembangan ekonomi lokal. Untuk lebih jelasnya dapat dilihat pada Tabel 2 berikut:

Tabel 2. Skor Penilaian Skala Likert

\begin{tabular}{cclc}
\hline No. & Kode Jawaban & \multicolumn{1}{c}{ Pilihan Jawaban } & Skor Penilaian \\
\hline 1 & SS & Sangat Setuju & 5 \\
2 & ST & Setuju & 4 \\
3 & RG & Ragu-Ragu & 3 \\
4 & TS & Tidak Setuju & 2 \\
5 & STS & Sangat Tidak Setuju & 1 \\
\hline
\end{tabular}

Untuk mengetahui sejauhmana respon masyarakat terkait dengan variabel Keterisolasian desa, aksesibilitas jaringan jalan dan partisipasi masyarakat terhadap peningkatan ekonomi masyarakat melalui pembangunan infrastruktur perdesaan melalui program PNPM PISEW.
Selanjutnya dengan teknik pengumpulan data angket, maka instrument tersebut akan dibagikan kepada responden sebagai sampel yang telah ditetapkan berdasarkan jumlah populasi. Sebagai contoh Pendekatan Proses Pengolahan Data dengan skala Likert. Jika jumlah sampel atau responden diambil sebesar 30 orang dari hasil secara random atau acak, dan berdasarkan hasil tabulasi data menunjukkan :

- 5 orang menjawab Sangat Setuju

- 19 orang menjawab Setuju

- 3 orang menjawab Ragu-Ragu

- 2 orang menjawab Tidak Setuju

- 1 orang menjawab Sangat Tidak Setuju

Berdasarkan data tersebut diatas 24 orang atau $80 \%$ jawaban menjawab Sangat Setuju dan Setuju, maka kesimpulannya mayoritas sampel menjawab Setuju dengan bahwa variabel keterbukaan isolasi, aksesibilitas dan partisipasi masyarakat mampu meningkatkan ekonomi masyarakat. Untuk menghitung data interval tersebut dapat dianalisis dengan menghitung rata-rata jawaban berdasarkan scoring setiap jawaban dari responden. Berdasarkan skor yang telah ditentukan dapat dihitung sebagai berikut :

- Jumlah skor untuk 5 orang yang menjawab SS = 5 x 5 $=25$

- Jumlah skor untuk 19 orang yang menjawab $S=19 x$ $4=76$

- Jumlah skor untuk 3 orang yang menjawab $R G=3 x$ $3=9$

- Jumlah skor untuk 2 orang yang menjawab TS $=2 \times 2$ $=4$

- Jumlah skor untuk 1 orang yang menjawab STS $=1 \mathrm{x}$ $1=1$

Jadi Total Jumlah Skor $=115$

Jumlah skor ideal untuk seluruh item $=30 \times 5=150$, artinya jika seluruh responden menjawab Sangat Setuju (SS). Jumlah skor yang diperoleh dari penelitian $=115$. Jadi berdasarkan data itu maka tingkat persetujuan terhadap Ketiga variabel meningkatkan ekonomi masyarakat $=(115$ : $150) \times 100 \%=76,66 \%$. Secara Kontinum dapat digambarkan sebagai berikut :

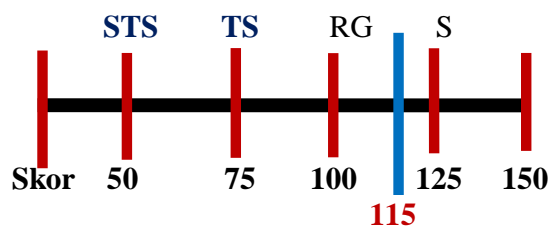

\section{Hasil dan Pembahasan}

Hasil analisis digunakan pengukuran skala Likert, yang terfokus pada variabel Keterisolasian, Aksesibilitas dan Partisipasi Masyarakat. Sebagaimana hasil pengukuran yang diperoleh berikut:

a. Hasil Analisis Variabel Keterisolasian Desa

Pembahasan tentang pentingnya Program PNPMPISEW terhadap keterisolasian desa, sebagai berikut: Jumlah sampel atau responden diambil sebesar 100 orang dari hasil secara random atau acak, dan berdasarkan hasil tabulasi data menunjukkan (Tabel 3). 
Tabel 3.Jawaban Responden pada Variabel Keterisolasian Desa

\begin{tabular}{clc}
\hline No. & Jenis Jawaban & $\begin{array}{c}\text { Jumlah Responden yang Menjawab } \\
\text { (Orang) }\end{array}$ \\
\hline 1 & Sangat Setuju & 4 \\
2 & Setuju & 79 \\
3 & Ragu-Ragu & 17 \\
4 & Tidak Setuju & 0 \\
5 & Sangat Tidak Setuju & 0 \\
\hline \multicolumn{2}{l}{ Sumber: Analisa Data, 2019 }
\end{tabular}

Berdasarkan Tabel 3, sebanyak 83 orang atau 83,00\% jawaban menjawab Sangat Setuju dan Setuju, maka kesimpulannya mayoritas sampel menjawab Setuju terhadap pentingnya Program PNPM-PISEW Terhadap Keterbukaan Isolasi Desa. Untuk menghitung data interval tersebut dapat dianalisis dengan menghitung rata-rata jawaban berdasarkan scoring setiap jawaban dari responden. Berdasarkan skor yang telah ditentukan dapat dihitung sebagai berikut:

TabeL 4. Hasil Jawaban Responden dan Nilai Skor Pada Variabel Keterisolasian Desa

\begin{tabular}{clcc}
\hline No. & Jenis Jawaban & $\begin{array}{c}\text { Jumlah Responden } \\
\text { yang Menjawab } \\
\text { (Orang) }\end{array}$ & Skor \\
\hline 1 & Sangat Setuju & 4 & 4 X 5 = 20 \\
2 & Setuju & 79 & 79 X 4 = 316 \\
3 & Ragu-Ragu & 17 & 17 X 3 = 51 \\
4 & Tidak Setuju & 0 & 0 X 2 $=0$ \\
5 & Sangat Tidak Setuju & 0 & 0 X 1 = 0 \\
\hline & & Total Jumlah Skor & $\mathbf{3 8 7}$ \\
\hline
\end{tabular}

Sumber: Analisa Data, 2019

Jumlah skor ideal untuk seluruh item $=100 \times 5=500$, artinya jika seluruh responden menjawab Sangat Setuju (SS). Jumlah skor yang diperoleh dari penelitian $=387$. Jadi berdasarkan data itu maka tingkat persetujuan terhadap keberadaan Program PNPM-PISEW $=(387: 500) \times 100 \%=$ $77,40 \%$.

Maka hasil yang diperoleh dari 100 responden dengan skor rata-rata 500, proses data dalam pembahasan diatas diperoleh skor 387 yang terletak antara Ragu-Ragu dan Setuju, artinya cenderung terletak masuk pada daerah Setuju dalam Skala Likert.

Tabel 5. Hasil Analisis Skala Likert Pada Aspek Keterisolasian Desa

\begin{tabular}{cccccc}
\hline No & Pertanyaan & Skor Ideal & $\begin{array}{c}\text { Skor } \\
\text { Hasil }\end{array}$ & $\begin{array}{c}\text { Tingkat } \\
\text { Persetujuan } \\
(\boldsymbol{\%})\end{array}$ & Ket. Hasil \\
\hline 1 & Nomor 1 & 500 & 387 & 77,24 & $\mathrm{~S}$ \\
2 & Nomor 2 & 500 & 436 & 87,20 & $\mathrm{~S}$ \\
3 & Nomor 3 & 500 & 441 & 88,20 & $\mathrm{~S}$ \\
4 & Nomor 4 & 500 & 447 & 89,40 & $\mathrm{~S}$ \\
5 & Nomor 5 & 500 & 443 & 88,60 & $\mathrm{~S}$ \\
6 & Nomor 6 & 500 & 451 & 90,20 & $\mathrm{SS}$ \\
\hline \multicolumn{2}{l}{ Nlai rata-rata } & $\mathbf{5 0 0}$ & $\mathbf{4 3 4}$ & $\mathbf{8 6 , 8 3}$ & S \\
\hline
\end{tabular}

Sumber: Analisa Data, 2019

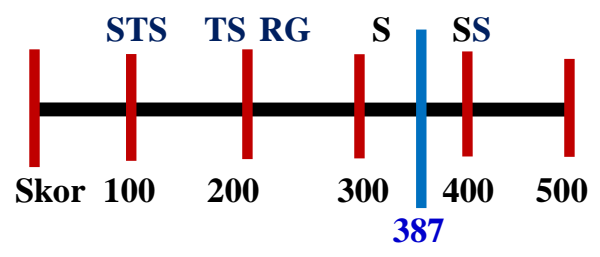

b. Hasil Analisis Variabel Aksesibiltas

Pembahasan tentang pentingnya Aksesibiltas, sebagai berikut: Jumlah sampel atau responden diambil sebesar 100 orang dari hasil secara random atau acak, dan berdasarkan hasil tabulasi data menunjukkan:

Pembahasan tentang pentingnya Aksesibiltas, sebagai berikut: Jumlah sampel atau responden diambil sebesar 100 orang dari hasil secara random atau acak, dan berdasarkan hasil tabulasi data menunjukkan.

Tabel 6. Hasil Jawaban Responden Pada Aspek Aksesibiltas

\begin{tabular}{clc}
\hline No. & \multicolumn{1}{c}{ Jenis Jawaban } & $\begin{array}{c}\text { Jumlah Responden yang } \\
\text { Menjawab (Orang) }\end{array}$ \\
\hline 1 & Sangat Setuju & 13 \\
2 & Setuju & 70 \\
3 & Ragu-Ragu & 17 \\
4 & Tidak Setuju & 0 \\
5 & Sangat Tidak Setuju & 0 \\
\hline Sumber: Analisa Data 2019
\end{tabular}
Sumber: Analisa Data, 2019

Berdasarkan data tersebut diatas 83 orang atau $83,00 \%$ jawaban menjawab Sangat Setuju dan Setuju, maka kesimpulannya mayoritas sampel menjawab Setuju terhadap pentingnya Aksesibiltas. Untuk menghitung data interval tersebut dapat dianalisis dengan menghitung ratarata jawaban berdasarkan skoring setiap jawaban dari responden. Berdasarkan skor yang telah ditentukan dapat dihitung sebagai berikut:

Tabel 7. Hasil Jawaban Responden dan Nilai Skor Pada Variabel Aksesibilitas

\begin{tabular}{c|l|c|c}
\hline No. & Jenis Jawaban & $\begin{array}{c}\text { Jumlah } \\
\text { Responden yang } \\
\text { Menjawab } \\
\text { (Orang) }\end{array}$ & Skor \\
\hline 1 & Sangat Setuju & 13 & 13 X 5 = 65 \\
2 & Setuju & 70 & 70 X 4 = 280 \\
3 & Ragu-Ragu & 17 & 17 X 3 = 51 \\
4 & Tidak Setuju & 0 & 0 X 2 = 0 \\
5 & Sangat Tidak Setuju & 0 & 0 X 1 = 0 \\
\hline \multicolumn{2}{|c}{ Total Jumlah Skor } \\
\hline
\end{tabular}
Sumber: Analisa Data, 2019

Jumlah skor ideal untuk seluruh item $=100 \times 5=500$, artinya jika seluruh responden menjawab Sangat Setuju (SS). Jumlah skor yang diperoleh dari penelitian $=396$. Jadi berdasarkan data itu maka tingkat persetujuan terhadap Pentingnya Aksesibiltas $=(396: 500) \times 100 \%=79,20 \%$.

Maka hasil yang diperoleh dari 100 responden dengan skor rata-rata 500 , proses data dalam pembahasan diatas diperoleh skor 396 yang terletak antara Ragu-Ragu dan Setuju, artinya cenderung terletak masuk pada daerah Setuju dalam Skala Likert.Selanjutnya pertanyaan berikut dianalisis dan dibahas analog dengan pertanyaan no.1 diatas. Sebagaimana dalam tabel hasil analisis dibawah :

Tabel 8. Hasil Analisis Skala Likert Pada Aspek Aksesibilitas

\begin{tabular}{cccccc}
\hline No & Pertanyaan & $\begin{array}{c}\text { Skor } \\
\text { Ideal }\end{array}$ & $\begin{array}{c}\text { Skor } \\
\text { Hasil }\end{array}$ & $\begin{array}{c}\text { Tingkat } \\
\text { Persetujuan } \\
(\boldsymbol{\%})\end{array}$ & $\begin{array}{c}\text { Ket. } \\
\text { Hasil }\end{array}$ \\
\hline 1 & Nomor 1 & 500 & 396 & 79,20 & $\mathrm{~S}$ \\
2 & Nomor 2 & 500 & 429 & 85,80 & $\mathrm{~S}$ \\
3 & Nomor 3 & 500 & 426 & 85,20 & $\mathrm{~S}$ \\
4 & Nomor 4 & 500 & 428 & 85,60 & $\mathrm{~S}$ \\
5 & Nomor 5 & 500 & 426 & 85,20 & $\mathrm{~S}$ \\
6 & Nomor 6 & 500 & 411 & 82,20 & $\mathrm{~S}$ \\
7 & Nomor 7 & 500 & 434 & 86,80 & $\mathrm{~S}$ \\
\hline \multicolumn{7}{r}{ Nlai rata-rata } & $\mathbf{5 0 0}$ & $\mathbf{4 2 1}$ & $\mathbf{8 4 , 8 9}$ & $\mathrm{S}$ \\
\hline \multicolumn{2}{l}{ Sumber: Analisa Data, 2019 }
\end{tabular}




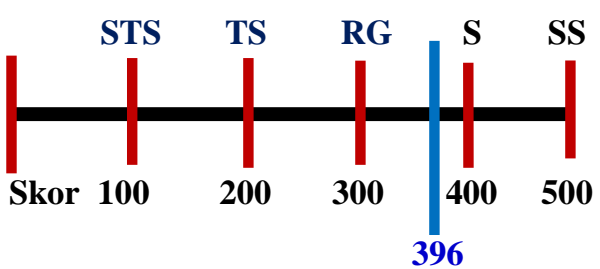

c. Hasil Analsisi Variabel Partisipasi

Jumlah sampel atau responden diambil sebesar 100 orang dari hasil secara random atau acak, dan berdasarkan hasil tabulasi data menunjukkan:

Tabel 9. Hasil Jawaban Responden Pada Aspek Partisipasi

\begin{tabular}{clc}
\hline No. & \multicolumn{1}{c}{ Jenis Jawaban } & $\begin{array}{c}\text { Jumlah Responden yang } \\
\text { Menjawab (Orang) }\end{array}$ \\
\hline 1 & Sangat Setuju & 31 \\
2 & Setuju & 59 \\
3 & Ragu-Ragu & 10 \\
4 & Tidak Setuju & 0 \\
5 & Sangat Tidak Setuju & 0 \\
\hline Sumber: Analisa Data, 2019
\end{tabular}

Berdasarkan data tersebut diatas 83 orang atau $83,00 \%$ jawaban menjawab Sangat Setuju dan Setuju, maka kesimpulannya mayoritas sampel menjawab Setuju terhadap pentingnya Aksesibiltas. Untuk menghitung data interval tersebut dapat dianalisis dengan menghitung ratarata jawaban berdasarkan skoring setiap jawaban dari responden. Berdasarkan skor yang telah ditentukan dapat dihitung sebagai berikut (Tabel 10).

Tabel 10. Hasil Jawaban Responden dan Nilai Skor Pada Variabel Partisipasi

\begin{tabular}{clcc}
\hline No & Jenis Jawaban & $\begin{array}{c}\text { Jumlah Responden } \\
\text { yang Menjawab } \\
\text { (Orang) }\end{array}$ & Skor \\
\hline 1 & Sangat Baik & 14 & 14 X 5 = 70 \\
2 & Baik & 70 & 70 X 4 $=\mathbf{2 8 0}$ \\
3 & Ragu-Ragu & 16 & 16 X 3 = 48 \\
4 & Tidak Baik & 0 & 0 X $2=\mathbf{0}$ \\
5 & Sangat Tidak Baik & 0 & 0 X 1 $1=\mathbf{0}$ \\
\hline & & Total Jumlah Skor & $\mathbf{3 9 8}$ \\
\hline Sumber: Analisa Data, 2019 & &
\end{tabular}

Jumlah skor ideal untuk seluruh item $=100 \times 5=500$, artinya jika seluruh responden menjawab Sangat Setuju (SS). Jumlah skor yang diperoleh dari penelitian $=398$. Jadi berdasarkan data itu maka tingkat persetujuan terhadap Partisipasi Masyarakat $=(398: 500) \times 100 \%=79,60 \%$. Maka hasil yang diperoleh dari 100 responden dengan skor rata-rata 500 , proses data dalam pembahasan diatas diperoleh skor 398 yang terletak antara Ragu-Ragu dan Setuju, artinya cenderung terletak masuk pada daerah Setuju dalam Skala Likert. Selanjutnya pertanyaan berikut dianalisis dan dibahas analog dengan pertanyaan no.1 diatas. Sebagaimana dalam tabel hasil analisis di bawah ini (Tabel 11).

Tabel 11. Hasil Analisis Skala Likert Pada Aspek Partisipasi

\begin{tabular}{lccccc}
\hline No & Pertanyaan & $\begin{array}{c}\text { Skor } \\
\text { Ideal }\end{array}$ & $\begin{array}{c}\text { Skor } \\
\text { Hasil }\end{array}$ & $\begin{array}{c}\text { Tingkat } \\
\text { Persetujuan } \\
(\%)\end{array}$ & $\begin{array}{c}\text { Ket. } \\
\text { Hasil }\end{array}$ \\
\hline 1 & Nomor 1 & 500 & 398 & 79,60 & Setuju \\
2 & Nomor 2 & 500 & 405 & 81,00 & Setuju \\
3 & Nomor 3 & 500 & 419 & 83,80 & Setuju \\
4 & Nomor 4 & 500 & 424 & 84,80 & Setuju \\
5 & Nomor 5 & 500 & 448 & 89,60 & Setuju
\end{tabular}

\begin{tabular}{|c|c|c|c|c|c|}
\hline 6 & Nomor 6 & 500 & 442 & 88,40 & Setuju \\
\hline 7 & Nomor 7 & 500 & 431 & 86,20 & Setuju \\
\hline 8 & Nomor 8 & 500 & 451 & 90,20 & $\begin{array}{l}\text { Sangat } \\
\text { Setuju }\end{array}$ \\
\hline & Nlai rata-rata & 500 & 427 & 85,45 & Setuju \\
\hline
\end{tabular}

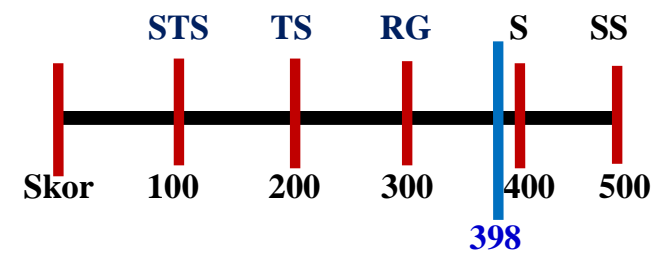

\section{Kesimpulan dan Saran}

Hasil penelitian dapat disimpulkan bahwa analisis pengaruh pembangunan infrastruktur jalan terhadap keterbukaan isolasi desa berdasar metode persentase menunjukkan angka 94,67\%, berdasarkan metode Skala Likert masuk pada kategori baik. Berdasar tiga variabel tersebut dapat dikemukakan melalui wawancara, bahwa sebelum program jalan terbangun pendapatan petani antara 1,5-2 juta rupiah perbulan, dan setelah terbangunnya jalan nilai ekonomi dari tahun ke tahun meningkat kurang lebih 3 juta rupiah perbulan pada tahun pertama operasional jalan.

\section{Daftar Pustaka}

Aziz, Iwan Jaya, 1985. Pembangunan Daerah dan Aspek Alokasi Investasi Antar daerah. Prisma No.6. pp. 321.

Daldjoeni, 1989. Geografi Kota dan Desa untuk mahasiswa dan guru SMU. Bandung: Penerbit Alumni.

Hudson, et al.,1997. Infrastruktur. Jurnal Infrastruktur, (Online), Vol. 1,No. 1.1, (http//www.tanimart. wordpress.com/infrastructure/ 1 infrastruktur.com, diakses 8 Mei 2013).

Kerlinger, 2006. Azas-azas Penelitian Behavior. Edisi 3 Cetakan 7. Yogyakarta: Gajah Mada University Press.

Kuncoro Mudrajad, 2010. Dasar-Dasar Ekonomi Pembangunan. Yogyakarta: UPP STIM YKPN.

Leibo Leifta, 1994. Sosiologi Pedesaan. Yogyakarta: Andi Offset.

Lexy. J. Moleong, 2007. Metodologi Penelitian Kualitatif. Bandung: Remaja Rosdakarya.

Perloff, Harvey and LowdonWingo Jr..1961. "Natural Resources Endowment and Regional Economic Growth. In Natural Resources and Economis Growth Ed, Joseph J. Spengler. Washington DC: Resources for the Future pp.191-212.

Poerwardaminta, 2003. Kamus Umum Bahasa Indonesia. Jakarta: Balai Pustaka.

Roscoe, 1982. Research Methods For Business. New York. Mc Graw Hill. Royan.

Sastropoetro, R.A.S.,1998. Partisipasi Komunikasi, Persuasi dan Disiplin Dalam Pembangunan. Bandung: Alumni

Sayogyo, 1986. Sosiologi Pedesaan. Jilid 2. Yogyakarta: UGM Press 
Sondang P.Siagian, 2008. Administrasi Pembangunan, Konsep, Dimensi dan Strateginya. Jakarta: Bumi Aksara.

Sugiyono, 2001. Metode Penelitian. Bandung: Alfabeta.

Sugiyono, 2003. Metode Penelitian Bisnis. Edisi 1. Bandung: Alfabeta.

Sugiyono, 2006. Metode Penelitian Administrasi dan Metode R\&D. Bandung: Alfabeta.

Sudjana, 1992. Metode Statistika. Edisi Kelima. Bandung: Tarsito.

Arikunto, Suharsimi. 1989. Metodologi Penelitian. Jakarta: Penerbit PT. Rineka Cipta.

Syamsi Yuswar Zainul Basri \& Mulyadi Subri, 2006. Keuangan Negara dan Analisis Kebijakan Publik. PT Raja Grafindo Persada.

Wresniwiro, 2012. Membangun Republik Desa. Jakarta: Visimedia.

Yuwono, 2001. Dasar-dasar Pengelolaan Master plan Pengelolaan dan Pengamanan Daerah Pantai. Laboratorium Hidrolik dan Hidrologi. Pusat Universitas Ilmu Teknik. Yogyakarta: Universitas Gajah Mada. 